\title{
Education Reforms for Equity and Quality: An Analysis from an Educational Ecosystem Perspective with Reference to Finnish Educational Transformations
}

HANNELE Niemi ${ }^{1}$

$\approx$ The article starts with the serious question of why educational reforms do not lead to better learning. Although access to education has increased remarkably, the quality of education can be very low. The reality is that by 2030 there will be 800 million young people who do not have basic skills in reading and math. The answers will be sought from the concept of the educational ecosystem and how different subsystems, such as curriculum system, evaluation systems, teacher education policy, and the labour market, should be interconnected, and the systemic changes supported by all these subsystems. The basic conditions are that different actors and stakeholders work in collaboration, there are active interactions within and between different subsystems for supporting both equity and quality in education. Educational reforms are complex processes and need diverse partners and governance in which trust is present. The article also provides a brief case description in Finnish contexts of how educational reforms have been implemented in the frame of the ecosystem concept. In the end, the article summarises how educational ecosystems could help in overcoming global learning crises.

Keywords: education ecosystem, education reforms, interconnectedness, communication, diversity 


\section{Šolske reforme za pravičnost in kakovost: analiza $\mathrm{z}$ gledišča izobraževalnega ekosistema s sklicevanjem na finske izobraževalne preobrazbe}

HANNELE NiEMI

C Članek se začne $\mathrm{z}$ resnim vprašanjem, zakaj šolske reforme ne vodijo $\mathrm{k}$ boljšemu znanju. Čeprav se je dostop do izobrazbe znatno povečal, je kakovost izobraževanja ponekod zelo nizka. Resničnost je takšna, da bo do leta 2030800 milijonov mladih, ki ne bodo opremljeni s temeljnimi veščinami branja in matematike. Odgovore smo iskali v zasnovi izobraževalnega ekosistema in tem, kako naj bi bili različni podsistemi (kot so na primer: kurikularni sistem, evalvacijski sistemi, politika izobraževanja učiteljev in trg dela) medsebojno povezani, sistematične spremembe pa podprte s pomočjo vseh teh podsistemov. Osnovni pogoji uspešnega delovanja so sodelovanje različnih udeležencev in interesentov, da se znotraj podsistemov in med podsistemi izoblikuje aktivno vzajemno delovanje, ki bi podprlo pravičnost in kakovost v izobraževanju. Šolske reforme so zapleteni procesi, ki zahtevajo raznolikost partnerjev in upravljanje, pri čemer je prisotno zaupanje. Članek prav tako ponudi bežen opis primera, kako so bile izvedene šolske reforme skladno s konceptom ekosistema v finskih kontekstih. Na koncu članek povzema ideje o tem, kako bi izobraževalni ekosistemi lahko pomagali pri premagovanju svetovnih učnih kriz.

Ključne besede: izobraževalni ekosistem, šolske reforme, medsebojna povezanost, komunikacija, raznolikost 


\section{Introduction - Why do educational reforms fail?}

Education is a term, even a slogan, that encompasses almost all issues when societal reforms are envisioned. In many political documents and international recommendations, education is seen as a primary solution to many challenges.

The European Commission (2017, p. 1) noted:

Good education underpins inclusive and resilient societies. It is the starting point for a successful professional career and the best protection against unemployment and poverty. It fosters personal development and lays the basis for active citizenship. Good education fuels $R \& D$, innovation, and competitiveness. However, for societies to reap these benefits, high-quality education needs to be a reality for all.

The World Bank (2018, p. 38) described education this way:

Education is a basic human right, and it is central to unlocking human capabilities. It also has tremendous instrumental value. Education raises human capital, productivity, incomes, employability, and economic growth. But its benefits go far beyond these monetary gains: education also makes people healthier and gives them more control over their lives [...] generates trust, boosts social capital, and creates institutions that promote inclusion and shared prosperity.

High-quality education is seen as a powerful tool and grounds for the success and well-being of individuals and society as a whole. The same message comes from the Organisation for Economic Co-operation and Development (OECD) $(2012,2018)$. The United Nations Educational, Scientific and Cultural Organization (UNESCO) and the United Nations Children's Fund (UNICEF) have emphasised that high-quality education is a human right (UNICEF, 2014, 2020; UNESCO, 2018).

Examining the global situation more closely uncovers many contradictions. Traditional factors, such as race, ethnicity, gender, geographical residence, language and minority status, can be tied to school failure and lack of access to education. Although access has increased remarkably in the last 20 years, over 250 million children still do not attend school if secondary school-age children are counted in the statistics (UNESCO, 2018; UNESCO Institute for Statistics (UIS), 2019; World Bank, 2018). Presently, access to primary level education has increased globally to more than $90 \%$, but schooling in the early years does not 
guarantee the achievement of secondary level outcomes. The most alarming fact is that in several low-income and even mid- and high-income countries, many students do not achieve the lowest basic skills in math and reading, despite having attended school for several years. UNESCO forecasted that by 2030 , more than 800 million children will lack these skills (UNESCO, 2018; UIS, 2019; World Bank, 2018). Therefore, an urgent challenge is addressing low-quality education. Many researchers are concerned about inequalities and the ability of schools to provide high-quality learning opportunities to different learners, also those who have learning difficulties (e.g., Ainscow, 2016; Garira, 2020; Gorard \& Smith, 2007; Kyriakides et al., 2020; Lee \& Manzon, 2014; Trifonas, 2003). The European Commission (2017, p. 1) recognised that 'the quality of education is decisive for young peoples' prospects and life chances... Education also plays a critical role in the European Pillar of Social Rights'. Most countries have initiated reforms that will provide wider access to education, but the problem of low quality still exists. UNICEF (2020) has announced the following:

Quality education, which is essential to real learning and human development, is influenced by factors both inside and outside the classroom, from the availability of proper supplies to the nature of a child's home environment. Improvements in the quality of teaching can reduce dropout rates and ensure better retention and transitions from early childhood learning into primary and secondary education.

While in many countries, educational reforms have started to raise the quality of education, it is surprising that the goals of reforms are often not reached. The book Teaching the World's Teachers (Lefty \& Fraser, 2020) describes teacher education (TE) reforms in 11 countries and their connections to those countries' educational systems over the last two to three decades. The authors explain that political decisions have not been implemented, aims have not been accepted or have not been fully understood by practitioners and local authorities, parents or other stakeholders have not been included in reform processes. Multiple and varied reasons explain the failure of these reforms across different countries, while the fault is often also attributed to resource allocation and corruption. However, the serious consequence of this situation has been that equity and quality have not been connected. Indeed, equal opportunities are not sufficient if learning support systems and educational quality are lacking.

In this article, the major question investigated is why educational reforms do not lead to better learning. This issue is analysed in the educational ecosystem context. First, this concept is introduced; thereafter, it is used to understand general reform challenges globally. Finally, the concept is applied to a 
case analysis to describe educational reforms in the Finnish educational system. The research questions are as follows:

1. What is an educational ecosystem, and how can the concept help to understand educational reforms?

2. From the perspective of the educational ecosystem, what determines whether educational reforms achieve their goals?

3. How can the education ecosystem concept explain successes and challenges in previous Finnish educational reforms?

The study is a literature-based analysis and review. It is mainly based on policy level reports and reviews from international organisations, such as the OECD, World Bank, UNESCO and the UNESCO Institute for Statistics (UIS), the official source of internationally comparable data on education, science, culture, and communication. Another data source is research investigating themes related to educational reforms, particularly from equity and quality viewpoints. The data on the Finnish case descriptions are obtained from national policy sources and research published in international books and articles in which the authors analysed features of the Finnish educational system for international readers. For the theoretical analysis of systems and their reforms, concepts from the ecosystem paradigm that view educational systems as changing and living wholeness and beings more than separate parts are utilised. A critical theory and Habermas's (1987) ideas of processed segmentations in societies and communicative action are used for deepening the understanding of what occurs within human systems.

\section{What is an educational ecosystem, and how does it relate to reforms?}

The ecosystem concept has emerged in many disciplines, such as medicine and healthcare (Kahn et al., 2012; Walpole et al., 2016) and the social sciences (Oksanen \& Hautamäki, 2015; Schwind et al., 2016), as well as in educational discussions (Niemi, 2016, 2021a, b; Niemi et al., 2014). Ecosystems have also been used in technological contexts to describe the importance of different partners working together (Moore, 2006). Mars et al. (2012) analysed the value of this concept, noting that the metaphor for the biological ecosystem provides a fresh lens through which to view an inherently interconnected world.

Indeed, the concept of ecosystems is rooted in biology (e.g., Dowd, 2019; Mars et al., 2012). We have learned from ecological studies that systems function well when their various parts work together and much biological 
information flows among their constituents. Biological ecosystems are characterised by three essential features: 1) interconnectedness of constituents, 2) information flow throughout the system, and 3) diversity that ensures the health and growth of the system (Niemi, 2016; 2021a, 2021b). The ecosystem idea provides lenses and concepts that can be applied when analysing how educational reforms achieve their aims. We have two concepts in an educational discourse: educational system and educational ecosystem. In principle, they have the same structures and elements, but the educational ecosystem emphasises the interconnectedness of different parts and actors, their diversity and how they work together and share information as essential resources. In both concepts, macro-, mid-, and micro-levels exist. Figure 1 describes the levels and interconnectedness of the educational ecosystem.

\section{Figure 1}

The educational ecosystem

Note. Adapted from Niemi, 2021b, p. 6.

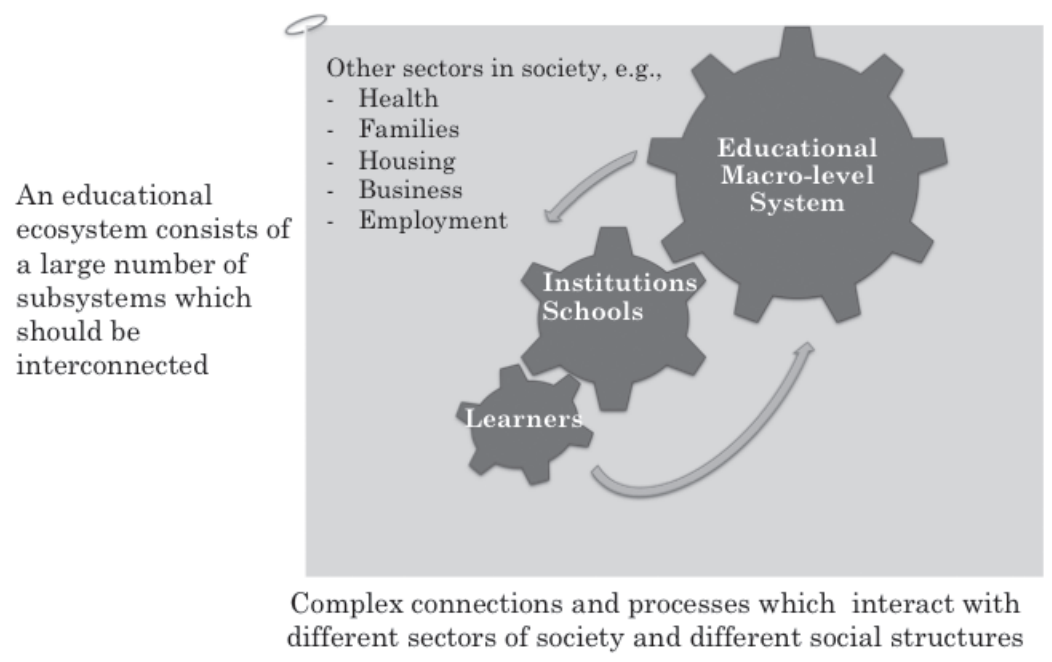

The macro-level consists of different structures in education, such as early education, pre-primary, primary, secondary, tertiary and adult education. It also involves comprehensive national or state-level strategies or processes, such as national/state curriculum and evaluation systems, TE, and training and lifelong learning strategies. Education also encompasses mid-level organisations and institutions, such as schools and universities, with their own structures, cultures, and forms of leadership. Micro-level systems in education comprise 
individuals, such as students and teachers, who have individual histories, life experiences, and genetic and neurological features.

When reflecting on educational reforms and how well they have achieved their aims, the ecosystem can be used as a conceptual tool for analysis. Niemi (2016, 2021a, 2021b) noted that an educational ecosystem is a complex living system and that it provides lenses through which connections and processes that interact within and between educational levels and actors can be examined. The diversity of reform partners plays an important role both within the educational ecosystem and with other systems. Connections with other ecosystems, such as healthcare, housing, social affairs, and employment, are crucial because it is through these that people are more empowered to access education and use their learning opportunities.

\section{Interconnectedness in reforms}

In educational system reforms, partners and actors must be connected and committed to common goals. This is a classic concept in the literature on how to lead educational change. However, this is not the reality of the situation. Sociologists, notably Habermas (1987), have described how systems in modern society can become separated and colonised through hierarchies and lack of communication. In education, subsystems can divide into segmented territories with their own aims, social practices, and power structures; eventually, collaboration among the parts vanishes. Systemic changes require that reforms also involve changes in other parts of the ecosystem. Broad national reforms can focus on a certain level, such as early education or adult education. Although the reform focuses only on one level, consequences are much wider, so changes are also needed at other levels. Transitions from basic education to secondary or from secondary to higher education can be difficult, even impossible, or cause students to drop out at the subsequent level (UNESCO, 2018). Therefore, students, teachers and parents must be prepared for changes to occur across the wider system.

Habermas (1987) also underscored the importance of interconnectedness. This message is also supported in recent leadership and management studies that emphasise commitment to joint aims for realising change. Researchers of systemic change have also presented the position, including Hargreaves et al. (2009), and since then, by many others (e.g., Garira, 2020; Pischetola \& de Miranda, 2020). Unfortunately, segmentation still exists in many sectors of education. For example, TE can be separated and segmented from the broader educational community, and in higher education, large gaps or tensions can exist between multiple academic and educational faculties that do not cooperate 
(e.g., Hudson, 2017). Thus, a lack of interconnectedness is often the reality at institutional levels in schools and universities that can develop territories among different disciplines that compete for time and resources.

Connections between school curricula, teachers' roles, and TE are essential. If interconnectedness between these components is loose or cooperation is strained, implementing changes can be challenging (e.g., LeTender, 2018; Wubbels \& van Tartwijk, 2018). Evidence from Singapore and Finland has verified how a strong connection between national curriculum systems and TE can lead to high learning performances, although these two systems differ in their educational governance (Low, 2018; Niemi et al., 2018). While differences, such as centralised versus decentralised systems, exist, the common essential factor is that multiple parts of the system and their actors cooperate to achieve common goals.

Field et al. (2007) and the OECD (2012) observed that curricula systems host many connections to the whole educational system and lifelong learning. UNESCO (2020) reported that irrelevant curricula are one key reason why student learning outcomes are low. Curricula that are not relevant to students create difficulties for teachers and learners in local level implementations. Stabback (2016, p. 4) investigated what adds quality to a curriculum: 'Curriculum... provides the bridge between education and development - and it is the competencies associated with lifelong learning and aligned with development needs, in the broadest, holistic sense of the term, that span that bridge. The curriculum and its connections with evaluation systems are also crucial. In some countries, especially the United States, evaluation systems are based on standardised testing, competitiveness, and rankings (LeTender, 2018), limiting what is taught in schools. Reforms can fail, even if the national curriculum is revised when evaluations are grounded on measuring narrow outcomes and different concepts of knowledge.

When analysing how equity and quality are connected in different educational systems, Field et al. (2006, p. 6) proposed that OECD policy recommendations aim at tighter links between actors regarding several issues. First, early prevention of dropout is the best cure. Basic schooling should support and engage those who struggle at school as well as those who excel. Second, those at risk should be monitored using the information on attendance, performance, and involvement in school activities and linked to interventions to improve outcomes and prevent dropout. Third, upper secondary education needs to be attractive to more than just the academically inclined elite; good quality pathways without dead ends and useful links to the world of work should be offered. Fourth, smooth transitions prevent school failure and dropping out. Additional 
learning support at the end of secondary school may encourage students to stay in school. Finally, good quality vocational tracks are essential to removing academic hurdles from the entrance to general upper secondary education and enabling access to tertiary education from vocational programmes.

All these recommendations relate to connections between different levels and emphasise multiple forms of support needed to create routes to learning for all. Interconnectedness requires active mutual interactions and understanding of what happens throughout the system, including outside its domain. One tool for better interconnectedness is information sharing, discussed next.

\section{Information flow - knowledge and evidence in educational ecosystems}

At present, information sharing is technically easier than ever before. However, in educational systems, many problems related to having, sharing, and using knowledge exist. Biological ecosystems function well if the information is delivered and shared among constituents. In the context of human behaviour, what must be considered is not only whether the information is flowing but also what kind of information or knowledge is shared, how it is communicated and to whom. Information flows in biological ecosystems are not one-directional; the links that form human cooperation should not be either, as such communication requires mutual activities and dialogue.

In educational reforms, information and knowledge sharing is needed vertically through different levels of the system but also horizontally across partners. For example, changes in school curricula must be shared with university TE programmes, at school levels with parents and other stakeholders and also with other systems in society, particularly with workforce representatives. From the ecosystem viewpoint, these obstacles cause serious dysfunctions if information is not crossing borders and remains in segmented systems. If macro-level units and structures are working separately or are not connected with mid-level units like schools or TE institutions, achieving the aims of reform may be difficult.

UNESCO (2020) discussed the urgent fact that real knowledge for educational development and improvements is lacking. The Global Education Monitoring Report (UNESCO, 2020) claims that almost half of low- and middle-income countries do not collect enough educational data about children with disabilities. One effort to address that is the World Inequality Database on Education (WIDE), which brings together data from Demographic and Health Surveys (DHS), Multiple Indicator Cluster Surveys (MICS), national household surveys and learning achievement surveys from over 160 countries (UNESCO, 2020). The tool enables users to compare educational outcomes between 
countries, and between groups within countries, according to factors associated with inequality, including wealth, gender, ethnicity and location. The same lack of knowledge has been observed by the World Bank (2018), which has noted that many countries do not have trustworthy and comprehensive data about student learning.

Evidence-based policy has been an important discourse topic over the previous two decades in educational governance, raising the importance of the knowledge needed for policy-level decisions. This discussion involves many critical voices that provide input on what works and what does not (Biesta, 2006; Matsushita, 2017; Pawson, 2006). The main criticism has been that the data have been collected from a narrow perspective or do not reflect the true essence of education, ignoring important stakeholders like teachers. PISA measurements and other international performance measure results have been criticised for not giving sufficient consideration to local circumstances (Zhao, 2020). This raises the question of how we can trust the knowledge we have and what kind of knowledge is used in reform decisions. Reforms require high-quality data from multiple perspectives. In the context of information sharing, problems in evidence-based knowledge can be classified into various categories: lack of knowledge, false or unreliable knowledge, misuse of knowledge and no use of knowledge.

Information sharing creates openness. However, the question of legitimacy is also an essential issue in educational reforms and their objectives. Legitimacy concerns are raised based on who is included and excluded from the flow of information. Wheeler-Bell (2017) analysed curriculum reforms considering critical theory and different interpretations of difficulties. He emphasised that viewing curricula decisions as bureaucratic and technocratic solutions is not sufficient. Partners must have a feeling that their voice is heard within decision making (2017, p. 562):

Democratic legitimacy depends upon the people interpreting educational decisions as justified: legitimacy depends upon individuals collectively feeling that their voice-or at least someone representing their voice-was presented within the decision-making process, and the process for making decisions was fair and generally reasonable.

When individuals feel they are not properly represented, policies begin to lose legitimacy. Wheeler-Bell (2017) also referred to Habermas's (1975) communicative action and asserts that a legitimation crisis in curricula reforms means that individuals collectively do not feel that curricula are morally binding; as a result, there is a moral disconnection between the educational policies enacted and the people's acceptance of said policies. 
Wheeler-Bell (2017, p. 569) proposed that 'a critical theory of the curriculum could explain why curriculum decisions are unjustifiable and fail to meet the standard of generality'. He referred to Habermas and the elements of communicative action as follows:

[They are] oriented towards mutual understanding in which speakers engage in the intersubjective process of giving and taking reasons to each other with the intent of collectively coordinating social action. Communicative action has three functions-reaching understanding, coordinating action and the socialization of individuals-all of which contribute to the reproduction of the life world and a democratic society.

\section{Diversity as a reform resource}

In biological ecosystems, diversity in the form of different types of constituents is needed for the system to function well. In educational reforms, a variety of actors involved in different phases of the reforms are needed. The discussions on 'interconnectedness' and 'information sharing' presented previously indicate that partnerships are complicated in education. Who is considered a partner depends on structures, governance, participants' involvement, and the sense of legitimacy. In the business sector, innovations develop when a wide range of partners and capacities are involved (e.g., Moore, 2006). Moreover, the idea of learning communities is based on the assumption that teachers, students, parents and other stakeholders work together (Antinluoma et al., 2018; Stassen, 2003). Smith (2016) analysed TE's role in society and in educational systems and claimed that partnerships must extend beyond rhetoric and be based on long-term commitments and genuine aspirations to cooperate to improve education at all levels.

Diversity means that different kinds of actors contribute to the system. Harford and O'Doherty (2016) provided examples in the Irish context to explain the importance of inviting teachers to participate as partners in planning reforms rather than viewing them only as objects of reform. As the legitimacy crisis discussion revealed, including or excluding partners can have remarkable consequences on commitment levels. We often describe educational governance as centralised or decentralised. Burns et al. (2016, p. 16) explained that many countries have decentralised control of their educational systems, giving local school authorities greater autonomy to respond more directly to citizens' needs. The report also noted that 'stakeholders (such as teachers, parents, students and labour unions) have become more involved in decision-making about education policy; relationships among stakeholders and decision-makers have become increasingly dynamic and negotiable and diversity within school 
communities has increased'. It also seems that the border between the centralised and decentralised systems is not as strict as once assumed. Balancing national, regional, and local interests can be difficult, and finding consensus is not easy. Mason (2016) asserted that diversity and diverse partnerships require new approaches and analysis to determine how they should connect and balance responsiveness to local diversity with the ability to ensure national objectives.

Mason described today's educational systems as increasingly complex due to multiple layers of governance and a greater number of stakeholders involved than ever before. He stated that complex systems pose several challenges, as individual systems can no longer be examined in isolation. He also claimed that the study of complex systems requires examining how the various interconnections can form a coherent whole. How to connect national and local interests requires much discussion, negotiation, compromise and dialogue. Mason (2016, p. 254) stated: '[This means] the system displays properties that are beyond those possible to anticipate based on the system's constituent elements alone. The governance of such a system is thus no longer possible with traditional linear models of planning and steering.

Diversity in ecosystems demands new administrative cultures that shift from focusing on control to focusing on collaboration and trust between actors to combine ambitious aims of equity and quality. Cerna (2014, p. 36) states:

In education systems, trust is a key component that helps coping with complexity. It facilitates cooperation between stakeholders and reduces information and power asymmetries. Trust is central to smart accountability systems and a high level of professionalism. As with all complex systems, one element cannot be changed without others to follow. Feedback loops can then create vicious or virtuous cycles. Elements such as cooperation, smart accountability, professionalism and trust can positively reinforce each other,

\section{The educational ecosystem and previous Finnish educational transformations}

The Finnish educational system has become well-known since 2000 due to its high performances in the international PISA assessments (Välijärvi \& Sulkunen, 2016). Although Finland has experienced some declines in their results, still many countries have been interested to learn key features about the Finnish system because it differs from many other systems. In this section, the analysis of Finnish educational reforms from previous decades is investigated through the educational ecosystem lens. This section aims to analyse how 
interconnectedness, information sharing and diversity have been implemented in the Finnish educational reforms.

Equal opportunities in education were not an ideal nor a reality in 1950 s Finnish society. Major differences existed among the population in the context of education, despite the common obligation for all to attend elementary school enacted in 1921. Differences were significant between urban and rural areas as well as between the northern and southern regions. In the 1950s, of Finnish citizens over age 20, 29\% had no education; in rural areas, it was $35 \%$. Geographical differences were considerable: in the southern part of Finland, only $14 \%$ of adults over age 20 were uneducated, but in northern rural areas of Finland, almost 48\% fell into this category (Niemi \& Lavonen, 2020). Finnish researchers (e.g., Sahlberg, 2007, 2011, 2012; Simola, 2005) described that in those days, Finland had a parallel system in education in which ten-year-old children had to decide on their future prospects and careers. The educational system put individuals into one of two categories at this very early stage of their lives, thus creating a divided nation. Students had to seek entrance and pass examinations to enter academically oriented schools or take a route that led to vocational fields. If they selected the vocational route, they could not seek entrance to higher education. The academic schools very often charged tuition, which further strengthened the divide.

Planning for a new school model began, and between 1965-1971, several committees were established, much explorative work and joint planning was initiated, and many pilot studies were launched in various parts of the country. The new school law was eventually stipulated, and in 1968 the comprehensive school model was put into action. Without the cooperation of educational leaders, teachers, principals, political parties, workforce and economy representatives and the labour market and increasing demands for lifelong learning (Faure, 1972), the major reform probably would not have been possible. The implementation required extensive communication, joint activities, decisions and other actions, including the following (Laukkanen, 2006; Niemi \& Lavonen, 2020; Sahlberg, 2007, 2011): 1) new TE requirements raising primary school TE to the master's level; 2) the strong allocation of educational resources to lower secondary education at the beginning of the transformation and then increasingly for weak students and inclusion policy; 3) the discontinuation of streaming and ensuring lifelong learning; 4) new evaluation systems and commitment to enhancement-led principles in evaluations; 5) inviting partners to reforms, moving towards decentralisation in decision-making and asking varied stakeholders for input; and 6) establishing platforms for continuous collaboration and dialogue. 
The new school needed new kinds of teachers. Teaching in the school for the whole age cohorts was different than in parallel, differentiated schools. New TE programmes in universities were based on new concepts of teaching and learning, and teachers were expected to promote all learners' growth, have the most current research-based knowledge in pedagogy and in their disciplines, learn critical thinking and reflection for the profession and also become familiar with how knowledge is created through their own experiences with scientific work on their bachelor's and master's theses and other research studies as part of TE (Jakku-Sihvonen \& Niemi, 2006; Sahlberg, 2011). These changes required much cooperation within and between universities but also cooperation between the Ministry of Education and Culture and universities and their TE departments.

The revisions made TE one of the most popular academic programmes in universities, attracting highly talented and motivated students, and that many positive outcomes were identified, such as teachers' high professional competence, commitment to the profession and their contributions to local-level curriculum designers and school developers (Sahlberg, 2012). However, schools continuously face new challenges, and TE must address them. In the Finnish system, the collective platforms that provide informal benchmarking and borders played an important role. In TE, these have included regular deans' meetings, research conferences, joint research projects with scientific and popular publications and cooperative development projects for teachers' competence building. Two examples of these wider collective processes will illuminate this practice. When Finland joined the Bologna process and reformed all university degrees, national processes were launched in 2001-2004 in all disciplines, including educational sciences and TE (Jakku-Sihvonen \& Niemi, 2006). This provided a coordinated platform, financed by the Ministry of Education and Culture but led by academics, to discuss and jointly design new bachelor's and master's degrees. In the educational sciences, different partners (representatives of teacher educators, teacher and student unions, the labour market and local educational authorities) collaborated in discussions and steering groups. Based on this comprehensive cooperation, new decrees were enacted, starting in 2005. The official regulations, like the decrees, provide only frames; universities are autonomous in detailed implementations. The joint discussions and recommendations provided useful grounds for local actions and internal quality assurance.

The most recent example of comprehensive cooperation is the Teacher Education Forum (Niemi \& Lavonen, 2020), established by the Ministry of Education and Culture in February 2016 but entirely led by TE representatives and stakeholders. It aims to foster the renewal of TE to meet the newest challenges 
and to prepare a development programme for teachers' pre- and in-service education covering lifelong professional development. The core of the forum consists of almost 100 teacher educators, teachers, and other stakeholders, including experts from municipalities and teacher and student unions. The hundreds of Finnish municipalities are partners in the Teacher Education Forum's projects.

Initially, the comprehensive school maintained a tracking system, in which students were streamed into low, intermediate, and high achiever groups in math, the mother tongue, and foreign languages. This was a concession to the secondary school teachers and business representatives who were concerned that Finland would lose gifted children when they learned in the same schools in heterogeneous, mixed-ability groups (Niemi \& Lavonen, 2020). However, this tracking prevented lower-level groups from advancing because intermediate courses had to be completed. Thus, lifelong paths were cut short by the tracking system. The new school was created to ensure equity in education, so in the 1980s, tracking stopped, and instead of segregation, the schools provided extra teaching hours and special needs support for weak learners. The decision required much cooperation between different stakeholders. The trend towards inclusiveness, special needs education with support systems, and students' holistic well-being has continued and, in fact, has become more important but also more demanding because of the broad heterogeneity of students. Välijärvi and Sulkunen (2016) have summarised that since the first PISA measurements (2000), differences have grown between students from different socioeconomic statuses, with some still falling below the average of PISA countries. Differences in outcomes between genders have also increased, prompting much discussion on the kinds of support needed (Välijärvi \& Sulkunen, 2016).

Evaluation systems impact the whole educational system at all levels. The Finnish system includes certain features rarely found in other countries. The Finnish National Agency of Education (FNAE, previously the Finnish National Board of Education) determined already in the 1990s that Finland's education system did not employ standardised school achievement testing, that inspectorates, schools and teachers are not ranked, and that student evaluations must be encouraging (FNAE, 2018). The Finnish solution has been an enhancement-led evaluation system. As such, information and data are needed to inform future improvements but not for rankings and competition (Kumpulainen \& Lankinen, 2016). The Finnish Education Evaluation Centre (FINEEC) carries out evaluations from early childhood education to higher education, organising field-specific evaluations, thematic evaluations and learning outcome evaluations. FINEEC (2020) indicates on its website that it is based on trust, 
openness, interactions and enhancement-led evaluation. External education evaluation aims to support the education system in achieving its objectives'. Evaluating the prerequisites for educational equality and inclusion is one of the key areas of FINEEC's evaluation operations. Enhancement-led evaluation is also the main principle in student assessments. Schools and teachers are free to use the methods that best support student learning (Kumpulainen \& Lankinen, 2916).

All Finnish public sector governance, including governance of the educational system, began moving towards a more decentralised model in the mid-1980s to transition from a control focus towards more information-led steering. The most important aim was to make educational services as functional as possible at the local level. Curriculum development processes are also manifestations of decentralisation. Every tenth year, the national core curriculum for basic education is revised and updated (Vitikka et al., 2016). Because of decentralisation, only core curricula are designed at the national level, which provides frames for local schools' own curricula. Education providers at local levels, in practice cities, may determine implementations in cooperation with teachers, parents, and other interest groups. To ensure pupil welfare, the curriculum must be drafted in collaboration with authorities who are partners in local level implementations, particularly social and health services (Finnish National Board of Education, 2015). The process has become increasingly more participatory. Vahtivuori et al. (2014) explained that the last revisions began in 2012 as a preparatory phase that involved hundreds of expert hearings. Many working groups with teachers, teacher educators, and societal stakeholders, including teacher unions and labour market representatives, were established. After the wide interactive processes also incorporating Internet-based platforms, the core curriculum was accepted in 2014. Local authorities and school principals, teachers, students and parents had two years to design the local school-based curricula; full implementation commenced in 2016 in schools.

Typical in the Finnish educational system has been an effort to create interconnectedness. A strong commitment to equal opportunities in education from the 1970s has established a value basis that set common aims for equity, emphasising supporting different learners and a link to equity and quality throughout the system. Different educational levels and partners have attempted to connect to changes as early as possible. Systemic changes have frequently required new resource allocations and special support for inclusion and for those with learning difficulties. In international reviews, trust has been cited as a specific feature in the Finnish system (OECD, 2016). Sahlberg (2007, p. 147) described 'how steady improvement in student learning has been 
attained through Finnish education policies based on equity, flexibility, creativity, teacher professionalism and trust'. Enhancement-led evaluations and a participatory, decentralised curriculum system have facilitated different partners to work together. Although Finland has many good experiences with interconnectedness, open information and knowledge sharing among different partners in transformations, supporting the educational ecosystem is a never-ending process. Changes in society and work lives, economic situations, migration and the ageing population continuously present new demands (Niemi et al., 2016). Finland has many challenges to be solved: increasing gaps between learners from different socioeconomic statuses and gender differences in learning outcomes (Välijärvi-Sulkunen, 2016); indeed, still there is much work to be done, despite Finland's position as one of the top-performing educational countries in the world.

\section{Conclusion}

This study aimed to find out why educational reforms fail or be successful. The concept of the educational ecosystem was used as lenses in the analysis. The first and second research questions asked how the concept of the ecosystem can help understand educational reform and determine whether educational reforms achieve their goals. We could find much evidence for failures: if different parts of the educational systems do not work in close cooperation, share information, and invite partners who work at different levels or sectors of the system, there will be many risks that reforms do not achieve their aims. The ecosystem is based on three key premises; interconnectedness, information flow, and diversity; these are also the key determinants to successful educational reforms. The legitimacy of reforms can be only achieved if actors, such as policymakers, teachers., students, and parents, are invited to be partners from the preparing phase of the reform, and they are heard in different phases, and they are aware of the goals of the reforms.

The ecosystem lenses were also used in the analysis of the third research question, which asked how the ecosystem concept can explain successes and challenges in the previous Finnish educational reforms. We determined that the major national structural reform towards more equal education in the late $1960 \mathrm{~s}$ required interconnectedness throughout the system. New concepts of pedagogy and revisions in teacher education were needed to produce real changes in classrooms. We also can see that if the aim is to connect equity and quality in education, the inner barriers must be abolished and in attempts to find ways to support different learners to maximise their learning. The structural barriers, 
as such early tracking, prevented Finnish students from fully entering life-long learning paths. The educational structure was changed to be more flexible to different learners, even for those who fail at certain phases in learning. Aiming at equity requires much information sharing between different levels of the educational system for finding relevant and efficient support systems. The educational ecosystem also aids in understanding the role of evaluation. The interconnectedness and information flow are essential if evaluations should serve more improvements than control.

The most important condition for real cooperation and information sharing is that the different partners and stakeholders can trust each other. In Finland, the system is decentralised, and many responsibilities have been given to local schools and teachers. However, this is only possible if teacher education is also involved in reforms and ensures that teachers can work with the freedom that decentralisation will bring.

Many common issues were identified through the ecosystem lenses. How to lead changes in educational ecosystems is a process that needs more research. How to find legitimacy and mutual understanding are major questions that come from critical theory but nowadays also from totally different paradigms or domains. The OECD has also raised the discussion of trust and support in education. The recent global challenges in education require that educational systems and reforms are regarded as complex ecosystems. The ecosystem cannot be based on top-down power structures without real dialogue about developing interconnections, knowledge sharing and diversity (Burns et al., 2016; Cerna, 2014).

If educational systems want to provide high quality learning opportunities to all learners, the lenses of the educational ecosystem provide a frame to analyse transformation processes. While the ecosystem metaphor is useful for understanding and predicting the conditions that shape and influence systems, it is important to understand the differences between biological and human behaviour. Biological systems do not consciously plan for the future to be effective or influential or effect change. In natural environments, many processes occur based on the system's balance or imbalance. Human organisations and systems, however, are based on conscious human actions, strategic aims and commitments. This also concerns educational reforms and set high demands for interconnectedness, information sharing and diversity of actors. 


\section{References}

Collaboration as a strategy for promoting equity in education: Possibilities and barriers. Journal of Professional Capital and Community, 1(2), 159-172. https://doi.org/10.1108/JPCC-12-2015-0013 Antinluoma, M., Ilomäki, L., Lahti-Nuuttila, P., \& Toom, A. (2018). Schools as professional learning communities. Journal of Education and Learning, 7(5), 76-91. https://doi.org/10.5539/jel.v7n5p76 Biesta, G. J. J. (2007). Why 'what works' won't work: Evidence-based practice and the democratic deficit in educational research. Educational Theory, 57(1), 1-22.

Burns, T., Köster, F., \& Fuster, M. (2016). Education governance in action: Lessons from case studies. OECD Publishing. http://dx.doi.org/10.1787/9789264262829-en

Cerna, L. (2014). Trust: What it is and why it matters for governance and education. OECD Education Working Papers, No. 108. OECD Publishing. http://dx.doi.org/10.1787/5jxswcgot6wl-enOECD Dowd, M. (2019). Ecosystem: Definition, types, structure \& examples. Sciencing. https://sciencing. com/ecosystem-definition-types-structure-examples-13719218.html European Commission. (2017). School development and excellent teaching for a great start in life. Communication from the Commission to the European Parliament, the Council, the European Economic and Social Committee and the Committee of the Regions. https://op.europa.eu/en/ publication-detail/-/publication/aagffcoo-4524-11e7-aea8-o1aa75ed71a1

Field, S., Kuczera, M., \& Pont, B. (2007). No more failures. Ten steps to equity in education. OECD. http://dx.doi.org/10.1787/9789264032606-en

FNAE (Finnish National Agency of Education). (2018). Finnish education in a nutshell. https://www. oph.fi/sites/default/files/documents/finnish_education_in_a_nutshell.pdf

FINEEC (The Finnish Education Evaluation Centre). (2020). FINEEC. https://karvi.fi/en/fineec/ Garira, E. (2020). A proposed unified conceptual framework for quality of education in schools. SAGE Open, 10(1). https://doi.org/10.1177/2158244019899445

Gorard, S., \& Smith, E. (2004). An international comparison of equity in education systems. Comparative Education, 40(1), 15-28. http://dx.doi.org/10.1080/0305006042000184863

Habermas, J. (1987). The theory of communicative action, volume 2 - Lifeworld and system: A critique of functionalist reason. Beacon Press.

Harford, J., \& O'Doherty, T. (2016), The discourse of partnership and the reality of reform: Interrogating the recent reform agenda at initial teacher education and induction levels in Ireland.

Center for Educational Policy Studies, 6(3), 37-58.

Hargreaves, A., Lieberman, A., Fullan, M., \& Hopkins, D. (Eds.). (2009). Second international handbook of educational change. Springer.

Hudson, B. (2017). (Ed.). Overcoming fragmentation in teacher education policy and practice. Cambridge University Press.

Jakku-Sihvonen, R., \& Niemi, H. (2006). The Bologna process and its implementation in teacher education. In R. Jakku-Sihvonen \& H. Niemi (Eds.), Research-based teacher education in Finland. Reflections by Finnish teacher educators (pp. 17-30). Finnish Educational Research Association. 
Kahn, L. H., Monath, T. P., Bokma, B. H., GIbbd, E. P., \& Aguirre, A. A. (2012). One health, one medicine. In A. A. Aguirre, R. S. Ostfeld, \& P. Daszak (Eds.), New directions in conservation medicine: Applied cases of ecological health (pp. 33-44). Oxford University Press.

Kumpulainen, K., \& Lankinen. T. (2016). Striving for educational equity and excellence: Evaluation and assessment in Finnish basic education. In H. Niemi, A. Toom, \& A. Kallioniemi (Eds.), Miracle of education: The principles and practices of teaching and learning in Finnish schools (2nd ed., pp. 71-82). Sense Publishers.

Kyriakides, L., Creemers, B. P. M., \& Charalambous, E. (2019). Searching for differential teacher and school effectiveness in terms of student socioeconomic status and gender: Implications for promoting equity. School Effectiveness and School Improvement, 30(3), 286-308.

Laukkanen, R. (2007). Finnish strategy for high-level education for all. In N. C. Sognel \& P. Jaccard

(Eds.), Governance and performance of education systems. Springer.

Lee, W. O., \& Manzon, M. (2014). The issue of equity and quality of education in Hong Kong. The Asia-Pacific Education Researcher Asia, 23, 823-833. https://doi.org/10.1007/s40299-014-0214-1 Lefty, L., \& J. Fraser. J. (Eds.), (2020). Teaching the world's teachers (pp. 153-178). Johns Hopkins University Press.

LeTendre. G. K. (2018). Teaching in the USA: Decentralisation, inequality, and professional autonomy. In H. Niemi, A. Toom, A. Kallioniemi, \& J. Lavonen (Eds.), The teacher's role in the changing globalising world: Resources and challenges related to the professional work of teaching practices (pp. 91-108). Brill | Sense. https://doi.org/10.1163/9789004372573_oo9

Low, E.-L. (2018). The changing roles of teachers and teacher learning in the twenty-first century: The Singapore story. In H. Niemi, A. Toom, A. Kallioniemi, \& J. Lavonen (Eds.), The teacher's role in the changing globalising world: Resources and challenges related to the professional work of teaching practices (pp. 125-140). Brill | Sense. https://doi.org/10.1163/9789004372573_oo9

Mars, M., Bronstein, J., \& Lusch, R. (2012). The value of a metaphor: Organisations and ecosystems. Organizational Dynamics, 41(4), 271-280.

Mason, M. (2016), Complexity theory and systemic change in education governance. In Burns, T. and F. Köster (Eds.), Governing education in a complex world, (pp. 41-54). OECD Publishing. http:// dx.doi.org/10.1787/9789264255364-4-en

Matsushita, R. (2017). The paradox of evidence-based education: From the decline of education to abandonment of the theories of education (trans. N. Murray). Educational Studies in Japan: International Yearbook, 11, 101-119

Moore, J. F. (2006). Business ecosystems and the view from the firm. The Antitrust Bulletin, 51(1), $31-75$.

Niemi, H. (2016). Building partnerships in an educational ecosystem: Editorial. Center of Educational Policy Studies Journal, 6(3), 5-15. http://hdl.handle.net/10138/167262

Niemi, H. (2021a). Equity and quality as aims of education: Teachers' role in educational ecosystems. In E. Kuusisto, M. Ubani, P. Nokelainen \& A. Toom (Eds.), Good teachers for tomorrow's schools: Purpose, values, and talents in education (pp. 19-36). Brill. https://brill.com/view/title/60323 
Niemi, H. (2021b). Teacher education in at the crossroads - Educational ecosystems for equity and quality of learning. In Envisioning the teaching and learning of teachers for excellence and equity in education, (pp. 5-23). Springer.

Niemi, H., \& Lavonen, J. (2020). Teacher education in Finland: Persistent efforts for high-quality teachers. In L. Lefty, \& J. Fraser (Eds.), Teaching the world's teachers (pp. 153-178). Johns Hopkins University Press.

Niemi, H., Kallioniemi, A., \&. Toom, A. (2016). Epilogue: How to be prepared to face the future. In H. Niemi, A. Kallioniemi, \&. A. Toom (Eds.), The miracle of education: The principles and practices of teaching and learning in Finnish schools (2nd revised ed., pp. 277-283. Sense Publishers.

Niemi, H., Lavonen, J., Kallioniemi, A., \& Toom, A. (2018). The role of teachers in the Finnish educational system. In H. Niemi, A. Toom, A. Kallioniemi, \& J. Lavonen (Eds.), The teacher's role in the changing globalizing world (pp. 47-61). Brill | Sense. https://doi.org/10.1163/9789004372573_004 Niemi, H., Multisilta, J., Lipponen, L., \& Vivitsou, V. (Eds.) (2014). Finnish innovations and technologies in schools. Towards new ecosystems of learning. Sense Publishers OECD. (2012). Equity and quality in education: Supporting disadvantaged students and schools. OECD Publishing. https://www.oecd-ilibrary.org/docserver/9789264130852-en.pdf?expires=1603811705\&id= id\&accname $=$ ocid194948\&checksum $=\mathrm{EDoBFE} 160 \mathrm{E}_{3} \mathrm{~A} 84 \mathrm{E}_{9} \mathrm{CFAF} 1606 \mathrm{C}_{2} \mathrm{E}_{9} \mathrm{~B} 13 \mathrm{~F}$ OECD. (2018). Equity in education: Breaking down barriers to social mobility. PISA, OECD Publishing. https://doi.org/10.1787/9789264073234-en Oksanen, K., \& Hautamäki, A. (2015). Sustainable innovation: A competitive advantage for innovation ecosystems. Technology Innovation Management Review, 5(10), 24-30.

Pawson, R. (2006). Evidence-based policy. A realist perspective. Sage.

Pischetola, M., \& de Miranda, L. V. T. (2020). Systemic thinking in education and a situated perspective on teaching. Ciência \& Educação, 26. https://doi.org/10.159o/1516-731320200015 Sahlberg. P. (2007). Education policies for raising student learning: The Finnish approach. Journal of Education Policy, 22(2), 147-171.

Sahlberg, P. (2011). Finnish lessons: What can the world learn from educational change in Finland? Teacher College Press.

Sahlberg, P. (2012). The most wanted: Teachers and teacher education in Finland. In D. DarlingHammond \& A. Lieberman (Eds.), Teacher education around the world. Changing policies and practices (pp. 1-21). Routledge.

Simola, H. (2005). The Finnish miracle of PISA: Historical and sociological remarks on teaching and teacher education. Comparative Education, 41(4), 455-470.

Schwinda, J., Gilardia, K., Beasleyb, V., Mazeta, J., \& Smitha, W. (2016). Advancing the 'One Health' workforce by integrating ecosystem health practice into veterinary medical education. Health Education Journal, 75(2), 170-183.

Smith, K. (2016). Partnerships in teacher education:Going beyond the rhetoric, with reference to the Norwegian context. Center for Educational Policy Studies, 6(3), 17-36. 
Stabback, P, (2016). What makes a quality curriculum? A paper for UNESCO-IBE, Current and critical issues in curriculum and learning. UNESCO. https://unesdoc.unesco.org/ark:/48223/ pfoooo243975.locale $=$ en

Stassen, M. (2003). Student outcomes: The impact of varying living-learning community models. Research in Higher Education, 44(5), 581-613.

Trifonas, P. P. (Ed.) (2003). Pedagogies of difference rethinking education for social justice. Routledge. UNESCO. (2014). Teaching and learning: Achieving quality for all. UNESCO Publishing.

UNESCO. (2018). One in every five children, adolescents and youth is out of school worldwide.

UNESCO Institute for Statistics. http://uis.unesco.org/sites/default/files/documents/fs48-one-fivechildren-adolescents-youth-out-school-2018-en.pdf

UNESCO. (2020). Global education monitoring report, 2020: Inclusion and education: all means all.

UNESCO. https://unesdoc.unesco.org/ark:/48223/pfoooo373718

UNICEF. (2014). Child Rights Education Toolkit: Rooting Child Rights in Early Childhood Education,

Primary and Secondary Schools. UNICEF. https://www.unicef.org/media/63081/file/UNICEF-Child-

Rights-Education-Toolkit.pdf

UNICEF. (2020) Addressing the learning crisis: An urgent need to better finance education for the poorest children. UNICEF. https://www.unicef.org/media/63896/file/Addressing-the-learning-crisisadvocacy-brief-2020.pdf

Vahtivuori-Hänninen, S., Halinen, I., Niemi, H., Lavonen, J., \& Lipponen, L. (2014). A new Finnish national core curriculum for basic education and technology as an integrated tool for learning. In $\mathrm{H}$. Niemi, J. Multisilta, L. Lipponen, \& M. Vivitsou (Eds.), Finnish innovations \& technologies in schools: Towards new ecosystems of learning (pp. 21-32). Sense Publishers.

Välijärvi, J., \& Sulkunen, S. (2016). Finnish school in international comparison. In H. Niemi, A. Toom, \& A. Kallioniemi (Eds.), Miracle of education. The principles and practices of teaching and learning in Finnish schools (2nd ed., pp. 3-22). Sense Publishers.

Vallory, E. (2020). Preparing teachers for the schools we have or for the school we want? Challenges and changes in Catalonia (Spain). In L. Lefty \& J. Fraser (Eds.), Teaching the world's teachers (pp. 89-110). Johns Hopkins University Press.

Vitikka, E., Krokfors, L., \& Hurmerinta, E. (2016). The Finnish national core curriculum: Structure and development. In H. Niemi, A. Toom, \& A. Kallioniemi (Eds.), Miracle of education: The principles and practices of teaching and learning in Finnish schools (2nd ed., pp. 83-9o). Sense Publishers. Walpole, S. C., Pearson, D., Coad, J., \& Barna, S. (2016). What do tomorrow's doctors need to learn about ecosystems? Medical Teacher, 38(4), 338-356.

Wheeler-Bell, Q. (2017). Standing in need of justification: Michael Apple, R. S. Peters and Jürgen Habermas. Journal of Curriculum Studies, 49(4), 561-578. https://doi.org/10.1080/00220272.2017.1279219 World Bank. (2018). World development report 2018: Learning to realise education's promise. https:// doi.org/10.1596/978-1-4648-1096-1

Wubbels, T., \& van Tartwij. J. (2018). Dutch teacher and teacher education policies: Trends and ambiguities. In H. Niemi, A. Toom, A. Kallioniemi, \& J. Lavonen (Eds.), The teacher's role in the 
changing globalizing world: On resources and challenges related to the professional work of teaching practices (pp. 63-77). Brill Sense

Zhao, Y. (2020). Two decades of havoc: A synthesis of criticism against PISA. Journal of Educational Change, 21, 245-266.

\section{Biographical note}

HANNELE NiEmI, $\mathrm{PhD}$, is a professor and research director at the University of Helsinki. She has worked also as UNESCO Chair on Educational Ecosystems for Equity and Quality of Learning since 2018. Her research areas include educational policy issues, teacher education, learning in technology-assisted environments, and ethics in teaching and learning. She has a long experience of developing high quality teacher education in Finland and globally, and published much on teacher education. 